\title{
Nest site selection and reproductive parameters of the threatened Atlantic Royal Flycatcher (Onychorhynchus swainsoni) and their significance for conservation
}

\author{
Daniel F. Perrella ${ }^{1 *}$, Paulo V. Q. Zima ${ }^{1}$ and Mercival R. Francisco ${ }^{2}$
}

\begin{abstract}
Background: Patterns of rarity can be explained by reproductive rates, levels of endemism, and habitat specificity, and knowledge on these parameters is important to understand the levels of vulnerability of each species and to formulate conservation strategies. Here, we studied nest-site selection and breeding biology of the Atlantic Royal Flycatcher (Onychorhynchus swainsoni), a poorly known vulnerable bird endemic to the Brazilian Atlantic Forest.

Methods: We addressed nest site selection in three different levels: first, we searched for nests near and far from water to investigate whether birds could select water proximities to construct nests; second, we examined if they could select certain streams in detriment of others, and we analyzed the characteristics of used and non-used streams, and third, in streams in which nests were found, we addressed nest site selectivity by comparing a number of parameters between nest sites and random sites. Further, we provide information on breeding biology parameters related to annual fecundity.
\end{abstract}

Results: During five breeding seasons, we found 23 nests in a well-preserved forest continuum. All of the nests were constructed above water, and they were found in streams that were about $4 \mathrm{~m}$ in width, instead of smaller streams with about $1.5 \mathrm{~m}$ in width. Modeling analyses revealed that within the used streams, nests were constructed in sites with lower vegetation density in relation to random points, while stream width, water speed, and canopy cover presented no significant correlation. Atlantic Royal Flycatchers in our study had a 22-day incubation period and 24 to 27 -day nestling period. Overall nest survival was comparatively high (62\%), but clutch size was small ( $N=2$ eggs) and double-brooding was unlikely, which resulted in a low annual fecundity (1.4 \pm 0.9 fledglings per reproductive female). Along the nesting streams, we found an average of $1.62 \pm 0.07$ breeding pairs $/ \mathrm{km}$.

Conclusions: These data suggest that nesting habitat specificity and low annual fecundity are among the factors contributing to the rarity of the Atlantic Royal Flycatcher in large forest continuums and to its absence in fragmented environments. It reinforces the importance of large well-preserved forest continuums for the conservation of habitat specialist Atlantic Forest bird species.

Keywords: Atlantic Forest, Birds, Breeding biology, Daily survival rate, Endangered species, Specialized bird species

*Correspondence: dfperrella@gmail.com

1 Programa de Pós-Graduação em Ecologia e Recursos Naturais,

Universidade Federal de São Carlos, Washington Luiz km 235, São Carlos 13565-905, Brazil

Full list of author information is available at the end of the article

\section{Background}

Patterns of rarity of animal species can be explained mainly by large body size, low reproductive rates, large home ranges, requirement of pristine and stable environments, high habitat specificity, and high levels of

(c) The Author(s) 2021. This article is licensed under a Creative Commons Attribution 4.0 International License, which permits use, sharing, adaptation, distribution and reproduction in any medium or format, as long as you give appropriate credit to the original author(s) and the source, provide a link to the Creative Commons licence, and indicate if changes were made. The images or other third party material in this article are included in the article's Creative Commons licence, unless indicated otherwise in a credit line to the material. If material is not included in the article's Creative Commons licence and your intended use is not permitted by statutory regulation or exceeds the permitted use, you will need to obtain permission directly from the copyright holder. To view a copy of this licence, visit http://creativeco mmons.org/licenses/by/4.0/. The Creative Commons Public Domain Dedication waiver (http://creativecommons.org/publicdomain/ zero/1.0/) applies to the data made available in this article, unless otherwise stated in a credit line to the data. 
endemism (Goerck 1997; Primack 2006; Harnik et al. 2012). As rare species are also more susceptible to become threatened, knowledge on these parameters is essential for understanding the levels of vulnerability of the taxa (Goerck 1997; Beissinger 2000; Primack 2006; Birskis-Barros et al. 2019). Among birds, important characteristics determining annual productivity involve clutch sizes, reproductive phenology, nest survival, and renesting rates (Gilpin and Soulé 1986; Cuthbert et al. 2004; Pacífico et al. 2014). Further, habitat specificity and nest site selection can affect the density of reproductive pairs and the fate of the nests (Fondell and Ball 2004; Gjerdrum et al. 2005; Ocampo and Londoño 2015), being key parameters for population demography and viability (Machado et al. 2020). Understanding these parameters can contribute to indicate the types of habitats to be preserved, to understand the species decline in local areas, and to provide guidelines for species recovering plans (Gjerdrum et al. 2005; Zhu et al. 2012; Cheng et al. 2019).

The Brazilian Atlantic Forest is one of the five main world's hotspots of biodiversity (Myers et al. 2000), concentrating high levels of endemisms, and at the same time high levels of habitat loss, with only about 11 to $16 \%$ of its primary cover remaining (Ribeiro et al. 2009). It holds more than 830 species of birds, of which 217 are endemic, and many of them are vulnerable to extinction (Bencke et al. 2006; Hasui et al. 2018). However, even basic information needed for conservation planning are lacking for most species (Groves et al. 2002; Lu 2015; Xiao et al. 2016).

One such species is the Atlantic Royal Flycatcher (Onychorhynchus swainsoni). The distribution of this bird is restricted to the Atlantic Forest of eastern Brazil, from Minas Gerais and Rio de Janeiro, to Santa Catarina states (del Hoyo et al. 2019), and its current conservation status is "vulnerable" according to the International Union for Conservation of Nature (IUCN), mainly due to habitat loss. The population is thought to be decreasing, and the need for studies on its ecological requirements has been emphasized (BirdLife International 2019). Although some authors have suggested an association of nests of the Royal Flycatcher species to stream-side habitats (Von Ihering 1914; Parker et al. 1996; Sick 1997), specific studies on nest site selection are unavailable, and the Atlantic Royal Flycatcher breeding biology data are limited to the description of nests (Von Ihering 1914; Descourtilz 1983; Kirwan 2009) and eggs (Von Ihering 1914; Sick 1997; Mallet-Rodrigues et al. 2006).

Here we investigated nest site selection, breeding territory density, nesting success, and annual productivity of the Atlantic Royal Flycatcher in a well-preserved Brazilian Atlantic Forest continuum. Besides, we provide additional information on nests and eggs characteristics and breeding cycle. These data will be helpful to delineate conservation strategies for this Atlantic Forest endemic bird.

\section{Methods \\ Study area}

Our study was conducted at Carlos Botelho State ParkCBSP $\left(24^{\circ} 04^{\prime} \mathrm{S}, 47^{\circ} 58^{\prime} \mathrm{W}\right)$, part of one of the largest and better preserved continuous tracts of Atlantic Forest in southeastern Brazil, composed by Serra do Mar and Serra de Paranapiacaba (Mattoso et al. 2008). CBSP is a 37,644-ha remnant located in southeastern São Paulo State, where the predominant vegetation is primary ombrophylous dense forest, characterized by large trees $(25-30 \mathrm{~m})$, and a high diversity of epiphytes, lianas, and ferns (Oliveira-Filho and Fontes 2000; Lima et al. 2011). The local average temperature is between 18 and $20{ }^{\circ} \mathrm{C}$ (Ferraz and Varjabedian 1999). The annual average rainfall is $1676 \mathrm{~mm}$ (range $=777-2264 \mathrm{~mm}$ ), with a marked wet season from October to March and a dry season from April to September (Beisiegel and Mantovani 2006). Our study area was in the upper part of the Park, where elevation ranged from 700 to $760 \mathrm{~m}$ asl, and the vegetation is classified as submontane Atlantic Forest (OliveiraFilho and Fontes 2000). Also, included in our analysis was one nest found at Trilha dos Tucanos Lodge (TTL) (24 $00^{\prime} 17^{\prime \prime} \mathrm{S}, 47^{\circ} 33^{\prime} 45^{\prime \prime} \mathrm{W}, 723 \mathrm{~m}$ above the sea level), a private and well-preserved reserve located in the municipality of Tapiraí, dedicated to nature conservation and birdwatching ecotourism that is part of the same forest continuum, $45 \mathrm{~km}$ from Carlos Botelho State Park.

\section{Field procedures}

We conducted nest searches during five breeding seasons at CBSP, from September to February in 2013/2014, 2014/2015, 2016/2017 and 2017/2018, and from October to January in $2018 / 2019$. Field work was carried out by two to three observers, approximately $10 \mathrm{~h}$ per day. We used parts of 10 trails, totaling $9.2 \mathrm{~km}$, and parts of four streams, totaling $5.7 \mathrm{~km}$, as transects. Transects were searched at least two times a month, but not all of them were sampled every year (see Additional file 1). The trails were at least $100 \mathrm{~m}$ far from one another, and the streams were at least $500 \mathrm{~m}$ apart. Nests were located by inspecting structures similar to nests of Royal Flycatchers (untied pendulous tufts of vegetation) (Pinto 1953; Kirwan 2009), and also by inspecting adult birds in their territories (Martin and Geupel 1993).

\section{Nest site selection}

Nest site selection was examined at three different levels. First, as the few described nests were reported to be constructed above water (Von Ihering 1914; Parker et al. 
1996; Sick 1997), we compared nests frequencies along streams and along transects far from water to address whether our study species would indeed select water courses for nesting. Second, because the sampled streams could differ in their characteristics, i.e., width, depth, and canopy cover, we assessed whether birds could select certain streams. Third, within the streams in which nests were found, we compared four covariates between nest sites and random sites to assess nest site preferences by Atlantic Royal Flycatchers, including two variables related to vegetation (forest canopy cover and vegetation density around nest), and two related to stream characteristics (width and surface water speed). These river parameters were chosen because in theory they could reduce access to the nests by potential terrestrial nest predators (aqua-phobic nest predator hypothesis) (Collias and Collias 1984; Noske et al. 2013; Ocampo and Londoño 2015). Random sites were located $30 \mathrm{~m}$ from nests, and were established first by randomly choosing between up or downstream. Then, with the observer positioned in the middle of the stream, the closest branch that allowed measuring vegetation density at the same height of the reference nest was chosen as the random site. This third-level selection procedure was performed only during the 2016/2017, 2017/2018, and 2018/2019 breeding seasons, and nest-site variables were measured always just after fledging or nest failure.

We measured canopy cover using a spherical densiometer, following the manufacturer instructions (Convex Model-A, Forest Suppliers, Jackson, Mississippi, USA). This equipment, placed near the observer chest, was positioned in the four cardinal directions in nest sites and also in the random sites. Then, the numbers of grids (maximum 96) of the convex mirror presenting light reflects were counted. The values were averaged and multiplied by 1.04 to estimate the proportion of the canopy not covered by vegetation, and then this figure was subtracted from 100 to estimate canopy cover (Lemmon 1957).

Vegetation density around nest was measured by placing a measuring tape horizontally in nest lateral limits in the four cardinal directions, and also up and down, using the middle of the nest entrance as reference. Only the first $50 \mathrm{~cm}$ of the tape was considered to count the number of $10 \mathrm{~cm}$ intervals touched by vegetation. Then, vegetation density was estimated as the number of touched $10 \mathrm{~cm}$ intervals divided by all of the 30 intervals (Mezquida 2004). For the random sites, the observer used the closest point of the chosen branch to take these measurements.

For stream width, we measured the distance between the edges (water limits) directly below the nest or random site. Surface water speed was obtained by calculating the time that a standardized fluctuating plastic bottle took to travel a distance of $5 \mathrm{~m}$, with the nest or random site placed in the middle of its route. Because stream parameters can change due to the influence of rain, the above measurements were never taken within a period of three days after the last rain.

\section{Breeding biology data}

Nests were monitored using one or two infrared camera traps Bushnell TrophyCam, model 119437C (Bushnell Outdoor Products, Kansas, USA), programmed to capture $30 \mathrm{~s}$ videos (see also Ribeiro-Silva et al. 2018). For each nest, height above water and distance from the closest stream edge were obtained using a measuring tape, and nest dimensions were measured with a metal caliper $( \pm 0.5 \mathrm{~mm})$. After nest fate, we performed detailed observations on nest architecture and nest material, and we used the classifications proposed by Winkler (2004) for nest type and eggs shape. Measurements of eggs (length and width) were also taken with a metal caliper $( \pm 0.5 \mathrm{~mm})$, and they were weighed $( \pm 0.1 \mathrm{~g})$ with a spring scale (Pesola).

Nests were checked one to three times a week, but checking was intensified (daily) during laying, late incubation and late nestling stages to assess incubation and nestling periods. We avoided handling or touching nestlings in the nest to not interfere in nestling period duration (Skutch 1945). We determined clutch initiation dates from nests found in construction stage, and incubation initiation was determined by the presence of an incubating female or by the presence of warm eggs. The period of incubation was considered from the first day the eggs became warm to the day before hatching, and we considered nestling period from the day of hatching to the day before fledging (Winkler 2004; Oliveira et al. 2010). Nest predation was assumed when eggs or nestlings disappeared from the nest before fledging age, or when predation was recorded by the camera traps. Nests were considered successful when well-developed young disappeared from a nest in consecutive monitoring days, with no records of predators in the cameras.

\section{Frequency of reproductive pairs}

For estimating the frequency of breeding pairs along streams where nests were found, we divided the number of territories with active nests by the total length of rivers searched in each breeding season. These values were then averaged across the five breeding seasons to generate an estimate of numbers of nests per $\mathrm{km}$. As second nests in a breeding season were always constructed a few meters away from the first ones (see "Results" section), we assumed that they belonged to the same breeding pair. 


\section{Statistical analyses for nest site selection}

As only some rivers had nests, we tested whether this was somehow related to the stream traits (width, depth, and canopy cover). We measured these traits at 15 points from each of the four searched streams from CBSP, being these points $50 \mathrm{~m}$ distant one another. These points were not related to nest sites or to the random points used in the nest site selection analysis described below. Then, to assess what variables were contributing with the potential differences between these two stream categories (with and without nests), we compared each variable independently using simple unpaired $t$-tests with $z$-score transformed data, considering a 95\% confidence level.

To address nest site selection along streams where nests of Atlantic Royal Flycatchers were found, we compared nest sites with random sites based on the variables stream width, water speed, vegetation density, and canopy cover, using a Mixed Generalized Linear Model (GLMM), with binary distribution and logit link-function, and river as the random effect term. Modeling was performed using the R-package lme4 (Bates et al. 2015), with nest points coded as 1 and random points coded as 0 in the binary distribution. We report the parameter estimates of the model and their standard errors, with upper and lower 95\% confidence limits, to demonstrate the validity of the explanation of each variable. Further, we carried out $z$-tests to verify if each variable within the model was significantly different from zero. Prior to modeling, we tested for auto-correlation between variables using Pearson correlation test with the function rcorr provided in R-package Hmisc (Harrell Jr et al. 2019). We considered variables auto-correlated when $r \geq 0.7$ or when a significant correlation was found $(p \leq 0.05)$, and variables with less capacity to explain the data were removed from the analysis.

\section{Statistical analyses for nest survival}

The Daily Nest Survival Rate (DSR) was calculated for Atlantic Royal Flycatchers using the binominal Generalized Linear Model as proposed by Dinsmore et al. (2002), with maximum likelihood parameter estimates, using the Program Mark interface (White and Burnham 1999), implemented by the R-package RMark 2.2.6. (Laake 2013). Fates were coded as 0 for successful nests or 1 for predated nests, and we pooled samples from all breeding seasons to improve analysis effectiveness. Due to reduced sample sizes, only the null model of constant DSR was addressed. The null model contains only the intercept and did not aim to address the effect of environmental parameters in nest survival. For comparative purposes with other previous works related to reproductive parameters of birds, we also calculated the DSR using the method of Mayfield (1961). For both approaches, the cumulative probability of overall nest success could be estimated by raising DSR to the power corresponding the duration of the nesting cycle. Statistical analyses were performed using the Software R version 3.4.2 (R Development Core Team 2017).

\section{Results}

\section{Nest site selection}

During the five breeding seasons, we found 23 nests. All nests were located over water, but we found nests along only two of the four streams sampled in CBSP (Ribeirão Grande and Ribeirão das Pedras). The two streams where nests were not found (Fig. 1a) averaged $1.66 \pm 0.5 \mathrm{~m}$ in width (range $=0.88-2.99 \mathrm{~m}, n=30$ random points), and $8.7 \pm 3.2 \mathrm{~cm}$ in depth (range $=4.5-16 \mathrm{~cm}, n=30$ random points), whereas the two streams where we found nests (Fig. 1b) averaged $4.28 \pm 9.8 \mathrm{~m}$ in width (range $=2.6-$ $5.74 \mathrm{~m}, n=30$ random points) and $21.4 \pm 10.4 \mathrm{~cm}$ in depth (range $=8-41 \mathrm{~cm}, n=30$ random points). The $t$-tests indicated that these two groups of streams (with and without nests) differed in width $(t=-12.6$, $p<0.0001)$, and depth $(t=-6.9, p=0.0001)$, but did not differ in canopy cover $(t=0.1, p=0.96)$ (Fig. 2).

Sixteen nests found in the last three breeding seasons were used to address nest site selection along rivers where nests were found. Average, standard deviation (SD), and maximum and minimum values obtained for the four measured variables in nest sites and random sites within streams are presented in Table 1. The GLMM modeling including the covariates stream width, water speed, vegetation density, and canopy cover revealed vegetation density as the only significant parameter, which was negatively correlated to nest presence (Table 2), suggesting that this species chose nesting branches with less vegetation concealment.

\section{Frequency of reproductive pairs}

Considering only the streams where nests were found, the average number of breeding pairs was $1.62 \pm 0.07$ pairs $/ \mathrm{km}$ (range $=1.56-1.73$ pairs $/ \mathrm{km}$ ), and we found one nesting site every $618.4 \pm 24.04 \mathrm{~m}$ (range $=577-640 \mathrm{~m}$ ). Although we did not mark the birds, breeding territories could be identified as they were distant from each other and did not change within a same breeding season. Even when a second nesting attempt occurred (only two cases), second nests were constructed a few meters from the first nest (60 and $150 \mathrm{~m}$, respectively).

\section{Nesting information}

For three nests observed from the very beginning, the period of nest construction lasted 10, 20 and 21 days. For eight nests for which we could observe the end of construction, laying initiated after six to 22 days. In 

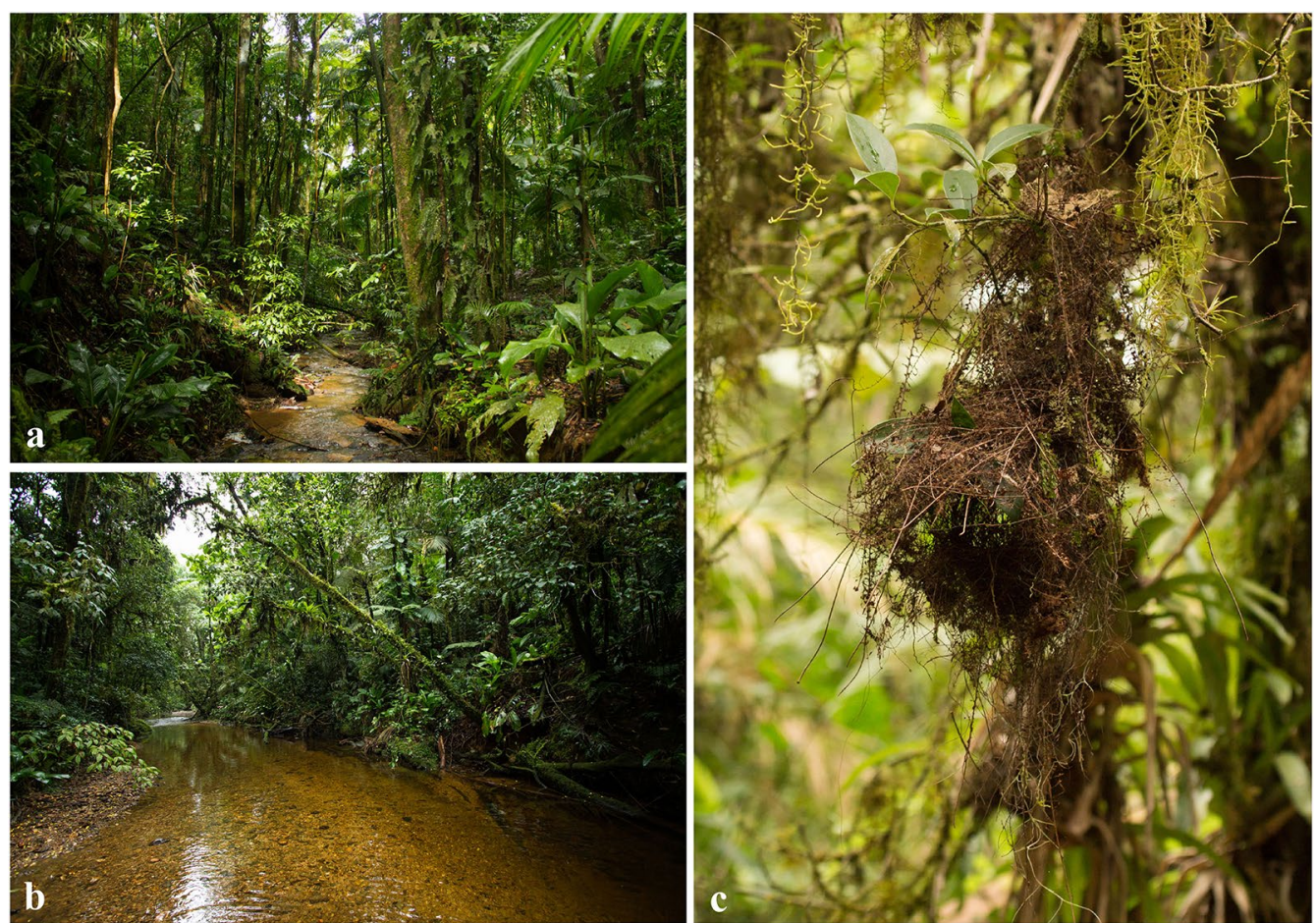

Fig. 1 a General overview of one of the smaller streams not used for nest construction at Carlos Botelho State Park, São Paulo state, Brazil. b A stretch of one of the streams selected for nesting in the same study area. c Nest of an Atlantic Royal Flycatcher
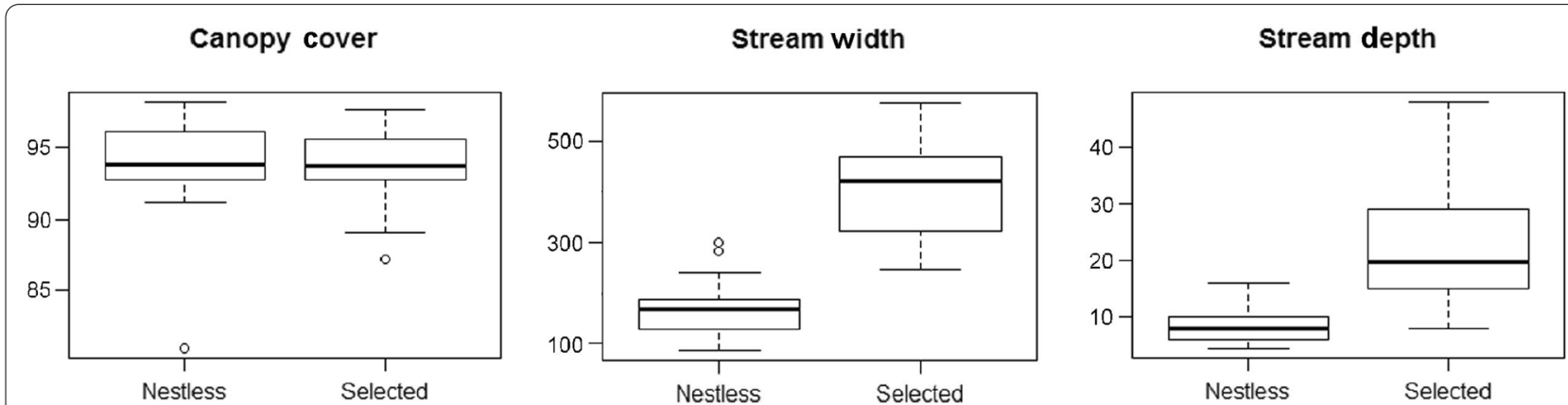

Fig. 2 Boxplots comparing canopy cover, width $(\mathrm{cm})$, and depth $(\mathrm{cm})$ of the two streams selected (Selected) by Atlantic Royal Flycatchers for nest construction joined together ( $n=30$ sampling points), and the two streams not used by the birds (Nestless) ( $n=30$ sampling points). Bold lines represent medians; the boxes delimit the upper and lower $25 \%$ quartiles; the dashed lines indicate the maximum and minimum values, and circles represent outliers. T-tests indicated that these streams have differed in width $(t=-12.6, p<0.0001)$, and depth $(t=-6.9, p=0.0001)$, but not in canopy cover $(t=0.1, p=0.96)$

Table 1 Average, standard deviation (SD), and maximum and minimum values obtained for four variables used to compare nest sites and random sites within streams chosen by Atlantic Royal Flycatchers for nesting

\begin{tabular}{lllll}
\hline Variables & Vegetation density & Canopy cover & Stream width $(\mathbf{c m})$ & Water speed $(\mathbf{m} / \mathbf{s})$ \\
\hline Nest sites & $3.3 ; \mathrm{SD}=2.3(1-9)$ & $91.7 ; \mathrm{SD}=2.6(88.3-96.7)$ & $513.7 ; \mathrm{SD}=146.4(275.0-838.0)$ & $0.3 ; \mathrm{SD}=0.1(0.03-0.6)$ \\
Random sites & $5.7 ; \mathrm{SD}=2.7(2-9)$ & $93.1 ; \mathrm{SD}=3.1(85.4-98.4)$ & $459.9 ; \mathrm{SD}=169.0(274.0-767.0)$ & $0.4 ; \mathrm{SD}=0.2(0.07-0.7)$ \\
\hline
\end{tabular}


Table 2 Results of GLMM binomial modeling used to compare nest and random sites within streams chosen by the Atlantic Royal Flycatchers for nesting, depicting parameters estimated values (Estimate), Standard Errors (SE), 95\% Confidence Intervals $(95 \% \mathrm{Cl})$, and values ( $z$-value) and probabilities ( $p$-value) of the $z$-statistic used to test if the parameters have differed significantly from zero

\begin{tabular}{lccccc}
\hline Variable & Estimate & $\mathbf{S E}$ & $\mathbf{9 5 \%} \mathbf{C l}$ & $\boldsymbol{z}$-value & $\boldsymbol{p}$-value \\
\hline (Intercept) & -0.09 & 0.45 & -1.074 to 0.864 & -0.199 & 0.84 \\
Vegetation & -1.15 & 0.49 & $\begin{array}{c}-2.299 \text { to } \\
(-0.274)\end{array}$ & -2.304 & $0.02^{\mathrm{a}}$ \\
$\begin{array}{l}\text { Density } \\
\text { Canopy cover }\end{array}$ & -0.37 & 0.53 & $\begin{array}{c}-1.528 \text { to } \\
0.6521\end{array}$ & -0.684 & 0.49 \\
& & & & \\
Stream width & 0.69 & 0.52 & -0.234 to 1.847 & 1.347 & 0.18 \\
Water speed & -0.79 & 0.50 & -1.899 to 0.134 & -1.570 & 0.12
\end{tabular}

a Significant correlation under a level of significance of $95 \%$

$2013 / 2014$, the first active nest was found under construction on 25 October 2013 and the last nestling fledged on 16 February 2014. In 2014/2015, the first nest was found on 7 October 2014 under construction, and the last nestling fledged on 22 January 2015.
In 2016/2017, the first nest was found on 28 October, in early nest construction stage, and the last fledging was in early March. In 2017/2018, the first nest was found under construction on 19 September and the last nest with nestlings was successful in late January. In 2018/2019, the first nest was found on 16 October during construction and the last nest was predated in 30 December. Although pooling all of the breeding seasons together results in a reproductive period that ranges from October to March (6 months, with peaks in November and December) (Fig. 3), each individual season never lasted much more than four months, indicating the existence of adjustments between years.

Nests were on average $1.88 \pm 0.38 \mathrm{~m}$ (range $=0.93$ $2.44 \mathrm{~m}, n=18)$ above water, and were $1.79 \pm 0.78 \mathrm{~m}$ (range $=0.19-3.15 \mathrm{~m}, n=13$ ) from the nearest stream edge. They were elongated pendulous domes, attached to slender malleable branches, so that the green leaves of the supporting branch could be seen pointing out from nest walls (Fig. 1c). Nests averaged $56.4 \pm 17.7 \mathrm{~cm}$ (range $30-104 \mathrm{~cm}$ ) in length, and nest chambers were located in the lowest section. Outer diameter of nest chamber was $88.1 \pm 16.6 \mathrm{~mm}$ (range $=52.9-117.8 \mathrm{~mm})$, inner cup diameter was $74.3 \pm 11.5 \mathrm{~mm}($ range $=53.3-87.7 \mathrm{~mm})$,

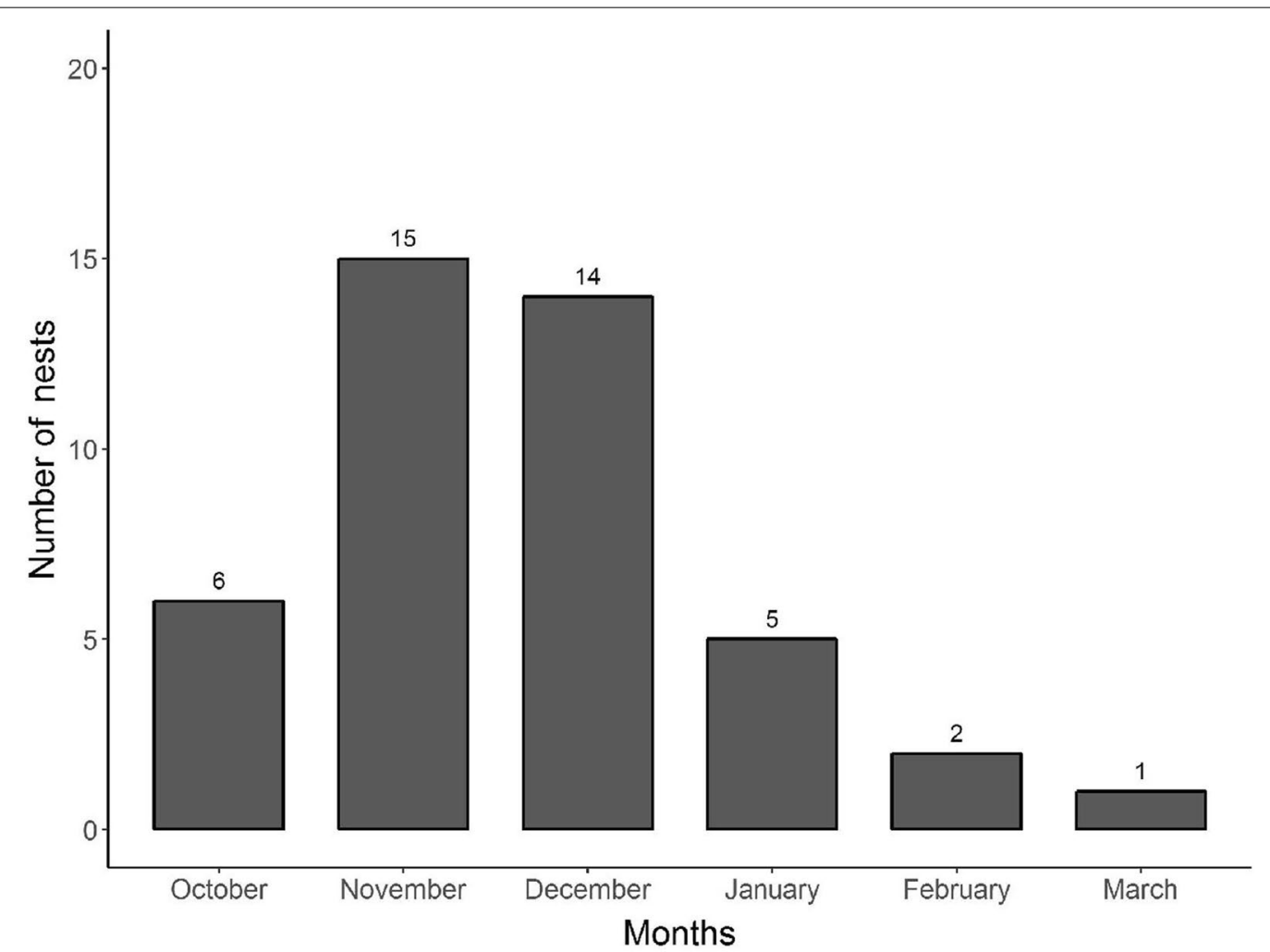

Fig. 3 Monthly distribution of active nests of Atlantic Royal Flycatchers, in incubation or nestling stage, pooling together five breeding seasons (2013/2014, 2014/2015, 2016/2017, 2017/2018, and 2018/2019), at Carlos Botelho State Park, São Paulo state, Brazil 
cup depth was $41.6 \pm 9.9 \mathrm{~mm}$ (range $=30.3-70.5 \mathrm{~mm}$ ), and the lateral entrance measured on average $72.3 \pm 8.2 \mathrm{~mm}$ (range $=56.6-81.8 \mathrm{~mm}$ ) by $52.3 \pm 8.1 \mathrm{~mm}$ (range $=42.9-69.9 \mathrm{~mm}) \quad(n=18$ nests $)$. The outer nest layer consisted of long and fine brown rootlets, small dried fern leaves, and some green leaves. The surface was adorned by large dried fern leaves, dried and twined leaves, loose tufts of green moss, and filaments of some green vascular plant, sometimes exceeding the bottom of the structure and forming a "tail" averaging $31.3 \pm 14.9 \mathrm{~cm}$ (range $=10-60 \mathrm{~cm} ; n=15$ nests) (Fig. 1c). Nest chamber was composed by finest rootlets loosely interwoven and with no inner lining, in such a way that eggs could be seen through the nest. An entrance porch of the same material of the outer layers was deposited over the nest entrances, hiding the incubatory chamber from above.

Clutch size was two eggs ( $n=16$ nests) or nestlings $(n=2)$, except for one nest with only one hatchling. In two nests found during construction, eggs were laid at one and two day intervals and incubation began the morning the second egg was laid. Incubation period was 22 d ( 2 eggs from one nest). Eggs were chalky textured and short-oval shaped, averaging $20.5 \pm 0.7 \mathrm{~mm}$ (range $=19.2-22 \mathrm{~mm}$ ) by $15.2 \pm 0.4 \mathrm{~mm}$ (range $=14.2-$ $15.7 \mathrm{~mm}$ ), and weighed $2.2 \pm 0.4 \mathrm{~g}$ (range $=1.5-2.8 \mathrm{~g}$, $n=14$ eggs from seven nests). Eggs were pinkish brown or reddish brown in background color, and wreathed with darker rufous scratches (Fig. $4 \mathrm{a}$ and b).

Hatching was synchronous in one nest and asynchronous in two nests, with an interval of approximately one day. For four young from two nests, nestling periods were $24 \mathrm{~d}$ and, for one young from one nest, nestling period was $27 \mathrm{~d}$. Hatchlings had pink skin, yellowish upperparts, closed eyes, and were devoid of down (Fig. 4c). Commissures were bright orange, the same color of the bill, which was grizzly in the upperparts (Fig. 4d). When nestlings became feathered, their heads and bodies upperparts were strongly streaked and the crest could already be noted (Fig. 4e). Nestlings always exposed their crests when an observer approached (Fig. 4f), a behavior that is common in the adults when they are mist-neted (MRF, pers. obs.).

\section{Reproductive success and annual productivity}

Of the 20 nests where fate was determined, six were lost to predation (30\%, two during incubation and four during nestling stages), one was abandoned during construction (5\%), and 13 were successful (65\%). DSR estimated using RMark was $0.988 \pm 0.004$ (0.975-0.995 of 95\% IC), which resulted in an overall survival probability (from egg laying to fledging) of 57\%. Using the Mayfield method, overall survival probability was $62 \%$ (583 nest days and six predation events in 19 nests).

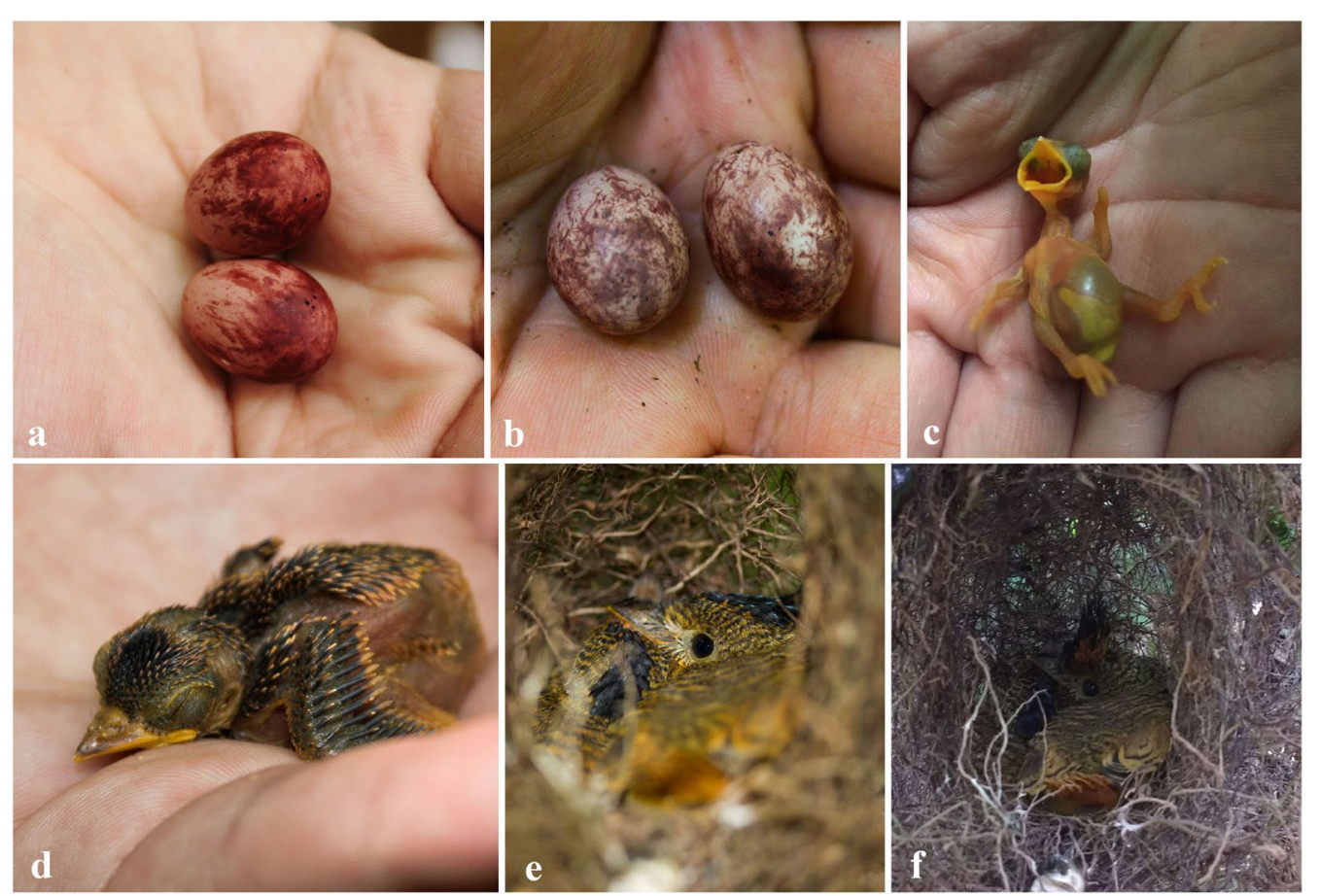

Fig. 4 a, b Eggs of Atlantic Royal Flycatchers. c Hatchling. $\mathbf{d}$ Middle-staged nestling, six to eight days old. e Two nestlings on late developmental stage, 23 to 25 days old. $\mathbf{f}$ Nestling exhibiting its crest (14 to 16 days old) 
Of the 19 nests where clutches were initiated, one fledged one young, 12 fledged two young each, and six nests failed before young fledged, resulting in an average production of $1.4 \pm 0.9$ fledglings per nesting attempt. We observed only four cases of second nesting attempts, two after predation of the first nest, followed by the construction of a second nest, and two cases of nest reuse after a successful brood: one nest was predated during incubation on 18 November 2014, and the construction of a second nest was detected on 23 November, with incubation initiation in early December, and fledging of young on 21 January 2015. In the second case, a nest also in incubation stage was predated sometime between 10 and 15 November 2017. The second nest was found under construction on 23 November, but it was abandoned a few days later and no more attempts of reproduction were detected by this pair in this season. The cases of nest reuse were observed only during the last studied breeding season (2018/2019). Two breeding pairs that were successful in their first nesting attempt, with fledging in late December 2018, were observed with eggs being incubated on 30 January 2019, but they were no longer monitored. Four other failed nests, depredated during nestling stage, showed no second nesting attempts. Of these nests, one was depredated in late November, two in middle December, and one in late January, suggesting that it could be too late in the breeding season for other nesting attempts.

\section{Discussion}

\section{Nest-site selection}

Our main finding was that Atlantic Royal Flycatchers were selective in relation to nesting site characteristics at the three levels of analysis. At the first level, birds built their nests over water, in detriment of river edges and forest areas far from water. At the second level, nests were found in only two of the four analyzed rivers, and the rivers used by the birds for breeding presented divergent characteristics in relation to the non-used ones, and in the third level, nest sites differed from random sites within the used streams in at least one of the four analyzed environmental covariates.

Although reports on the nests of other Royal Flycatcher species are scarce, nests of the Pacific Royal Flycatcher (Onychorhynchus occidentalis) were also described as built over forest streams (Tashian 1952). On the other hand, for the Amazonian Royal Flycatcher (O. coronatus) and for the Northern Royal Flycatcher (O. mexicanus), nests were found both over and far from water courses (Pinto 1953; Skutch 1960; Wetmore 1972; Whittingham 1994; Kirwan 2009; Tellkamp and Martin 2015), posing a question of whether nesting habitat specificities could be confounded by the fact that researchers often use streams to displace within forests, and by the fact that in the open riverine spaces nests could be easier to find. Our study of the Atlantic Royal Flycatcher is the first that compared empirically the frequencies of nests along forest streams and in transects far from water, and we provided the first evidences for the selection of nesting sites over forest streams for a Royal Flycatcher, which was corroborated by the confirmation that $100 \%$ of the nests were found over forest streams.

The streams used for nest construction were the wider and deeper ones. These streams were similar, but were much bigger than the two non-used ones. It is important to note that despite these differences, all of them were typical "forest streams", which is supported by the fact that they have not differed in the levels of canopy cover. Although it was clear that the Atlantic Royal Flycatcher excluded the smaller forest streams, we are unaware if they could construct nests along the biggest Atlantic Forest rivers that are, for instance, 10-15 m wide, and have forest canopy presenting large gaps. Using the concept of stream order of Horton et al. (1945), the smaller nonused water courses were second order streams, and the used ones were at least fourth order streams.

Although testing the evolutionary reasons for nest site selection is beyond the scope of this work, most theories rely on nest predation avoidance to explain nest site selection (see Chalfoun and Schmidt 2012a, b; IbáñezÁlamo et al. 2015). The Mayfield nest survival estimate of $62 \%$ in our study population of Royal Flycatchers was comparatively high. For the Yellow-Olive Flatbill (Tolmomyias sulphurescens), which is also a flycatcher that occurs in Atlantic Forest and constructs enclosed nests, Mayfield nest survival in forest fragments from Minas Gerais state was 26\% (Anciães et al. 2012). For other forest understory passerines from our same study area, nest survival was $57 \%$ for the Star-throated Antwren (Rhopias gularis) (Perrella et al. 2017), and 34\% for the Blue Manakin (Chiroxiphia caudata) (Zima et al. 2017). The construction of the nests in descending branches in the middle of the streams could be in theory an antipredatory strategy. Although they are more visually exposed it has been assumed that some terrestrial animals are unable or unwilling to cross water bodies to reach a nest (Robinson 1985; Noske et al. 2013; Ocampo and Londoño 2015). Some other birds build their nests along streams and rivers in Neotropical Forests (Armacost 2004; Greeney et al. 2006; Linhares et al. 2010; Perrella et al. 2015; Zima et al. 2017), and a number of works have revealed that large bodies of water can indeed increase birds' nesting success (Zoellick et al. 2004; Roldán-Clarà et al. 2013; Ocampo and Londoño 2015). Besides, the selection of branches with less foliage for nest construction can be an strategy to reduce access for arboreal predators (Skutch 1960), as 
the Grey Slender Mouse Opossum (Marmosops incanus) that was recorded by Ribeiro-Silva et al. (2018) depredating an Atlantic Royal Flycatcher nest, and also to reduce perching sites for flying animals (see also Peck 1908; Collias and Collias 1984), such as toucans and hawks that are frequent nest predators in the Atlantic Forest (Cockle et al. 2016; Ribeiro-Silva et al. 2018). Then, avoidance of certain types of predators can be a potential explanation for nest site selection in the Atlantic Royal Flycatcher, although the used strategies may not be efficient to avoid predation by bats, which were recently identified as nest predators in the study area (see Perrella et al. 2020).

\section{Reproductive biology}

The nesting season found in our study matched most of the observations of active nests of Atlantic Royal Flycatchers from other localities, i.e. one nest found in December in Teófilo Otoni, Minas Gerais state (Von Ihering 1914), three nests recorded in October and one in late November at Intervales State Park, state of São Paulo (Kirwan 2009), and to the eggs collected in October at São Bento do Sul, state of Santa Catarina (Mallet-Rodrigues et al. 2006). However, the breeding seasons of other Royal Flycatcher species, even poorly documented, are seen to be quite different, and vary according to latitude as it is observed for other species (Davanço et al. 2013). One nest of the Amazonian Royal Flycatcher was found during incubation in late September at Pará state, Brazil $\left(1^{\circ} \mathrm{S}\right)$ (Pinto 1953), while other nest was observed during nestling stage in August at Mato Grosso state, Brazil $\left(9^{\circ} \mathrm{S}\right)$ (Kirwan 2009). For the Northern Royal Flycatcher, Skutch (1960) observed the initiation of nesting activities in February in Panamá $\left(9^{\circ} \mathrm{N}\right)$, in early March at Southern Costa Rica $\left(8^{\circ} \mathrm{N}\right)$, and in April in Northern Central America $\left(15^{\circ} \mathrm{N}\right)$, while Tashian (1952) reported an active nest in early July in Mexico $\left(17^{\circ} \mathrm{N}\right)$.

Mallet-Rodrigues et al. (2006) and Kirwan (2009) also found clutch sizes of two eggs or young for the Atlantic Royal Flycatcher. Although a nest collected in the state of Minas Gerais was reported to have three eggs by Von Ihering (1914), it must be rare. The same clutch size (two eggs) also has been reported for other congeners, including the Amazonian Royal Flycatcher (Pinto 1953), and the Northern Royal Flycatcher (Skutch 1960). Although clutches of two eggs are typical of open-nester neotropical forest passerines (Jetz et al. 2008 for review; Londoño 2014; Marques-Santos et al. 2015), clutch sizes of closed-nester species are often larger. For other Atlantic Forest closed-nester flycatchers, for instance, clutch size is invariably three eggs for the Gray-hooded Flycatcher (Mionectes rufiventris) (Aguilar et al. 2000), and 3.4 (2-4) for the Yellow-olive Flatbill (Anciães et al. 2012), suggesting that the clutch size of the Atlantic Royal Flycatcher is relatively small.

For the Mexican Royal Flycatcher, Skutch (1945) reported incubation periods of 22 days for two nests, and nestling periods of 21-22 days for six nests. The incubation period we observed was similar but we recorded longer nestling periods (24 to 27 days) for the Atlantic Royal Flycatcher. Although here we provided incubation information for only one clutch, and nestling periods for only three clutches, together with the data of Skutch (1945) these are the only available information for the whole group. Incubation and nestling periods were 22 and 19.3 days, respectively, for the Gray-hooded Flycatcher (Aguilar et al. 2000), and 20 and 23 days for the Yellow-olive Flatbill (Anciães et al. 2012), being the reproductive cycle of the Atlantic Forest Royal Flycatcher only slightly longer than these.

Although information on renesting attempts are scarce for Neotropical birds, some works have reported the production of two, and sometimes three successful clutches in a season, i.e. for the Campo Suiriri (Suiriri affinis), the Chapada Flycatcher (S. islerorum) (Lopes and Marini, 2005), the Western Salty Antshrike (Thamnophilus atrinucha) (Roper 2005), the Pale-breasted Thrush (Turdus leucomelas) (Davanço et al. 2013), and for the Firewood-Gatherer (Annumbius annumbi) (Delhey et al. 2010). In the Atlantic Royal Flycatcher it seems unlikely, as second nesting attempts were rarely observed.

The frequency of breeding pairs along the sampled streams was also relatively low. In two works conducted in Amazon forest that addressed density estimates in 100 ha plots, the number of pairs of Amazonian Royal Flycatcher was 0.5 per plot, being among the lower densities found for passerine species within the sampled communities (Robinson and Terborgh 1997; Johnson et al. 2011). Estimating the density of pairs per hectare is beyond the scope of our work, however, the frequency of nesting pairs of the Star-throated Antwren, an Atlantic Forest passerine adapted to reproduce in stream edges, was more than three times greater than that of the Atlantic Royal Flycatcher in the same rivers and in the same reproductive seasons (average 5.35 nests $/ \mathrm{km}$, DFP pers. obs.). Although we are uncertain if we could have sampled some of the same individuals across years, we monitored up to seven territories with active nests simultaneously within a season. Furthermore, the numbers of nesting pairs and their locations changed between years, suggesting that our nest site selection data had a reduced effect of birds returning to the same nesting sites between seasons. 


\section{Significance for conservation}

Although specific works on Royal Flycatcher's diet are unavailable, they are known to capture small insects in flight (Fitzpatrick 1980; del Hoyo et al. 2019), in such a way that neither a specialized diet nor large body size may be among the parameters leading to the vulnerability of the Atlantic Royal Flycatcher. Further, it is not a target to the illegal pet trade that affects many other Neotropical passerine birds (Owens and Bennett 2000; Alves et al. 2012; Ubaid et al. 2018). Nonetheless, many birds surveys carried out in Atlantic Forest fragments located within the original distribution of the Atlantic Royal Flycatcher revealed the absence of this species (Willis 1979; Anjos and Boçon 1999; Dário et al. 2002; Ribon et al. 2003; Maia-Gouvêa et al. 2005; Pense and Carvalho 2005; Piratelli et al. 2005; Donatelli et al. 2007; Antunes and Eston 2008; Schunck et al. 2016; Perrella et al. 2018). Even in the larger and better preserved remnants (with 4900 to 10,000 ha) as the Serra da Cantareira State Park in São Paulo, the largest urban forest of the world, or in the complex of conservation units from Serra dos Orgãos in Rio de Janeiro, there are only historical records (Mallet-Rodrigues et al. 2007; Ayres 2008; Tonetti et al. 2017). We do not believe that the absence of the Atlantic Royal Flycatcher in these areas is due to low detectability. Although this species does not have a remarkable song, it has typical and loud calls that are easy to detect. It indicates that the need for large extensions of pristine habitats is behind the extinction of the Atlantic Royal Flycatcher in most of its original distribution, and our data suggest that reproductive adaptations can be involved in its low plasticity.

In birds, the combination of small clutch sizes, low renesting rates, and specialized nesting sites is often associated with higher susceptibility to extinction (Beissinger 2000). There is a general tendency for nest predation rates to be higher in small tropical forest fragments (Oniki 1979; Newmark and Stanley 2011; Rodrigues et al. 2018), and a potential explanation is the increase in the densities of mesopredator species as a result of the absence of the top predators (mesopredator release hypothesis, Terborgh 1974; Oniki 1979; Robinson and Sherry 2012), as well as the invasion of exotic nest predators (Owens and Bennett 2000). CBSP is connected to other important Atlantic Forest remnants from São Paulo state and, together with these conservation units, it composes an area of more than 1 million ha of forests (Mattoso et al. 2008). This is the region that best represents the original faunal composition of the Atlantic Forest from southeastern Brazil, with jaguars, cougars, ocelots, tapirs, and the large hawks still present (Brocardo et al. 2012; Antunes et al. 2013). This must be one of the reasons for the high nest survival rates we found, not only for the Atlantic
Royal Flycatcher, but also for other passerine species (Zima et al. in prep). It suggests that with such a small annual fecundity, the Atlantic Royal Flycatcher may be dependent on high nest survival rates, and disequilibrium in nest predation rates typical of fragmented areas could affect the viability of populations of the Atlantic Royal Flycatcher more than many other passerine species.

Theoretically, annual fecundity also could be affected by the lack of adequate nesting sites in forest remnants (Martin 1993; Cornell and Donovan 2010; Rodrigues et al. 2018). In most small Atlantic Forest fragments, streams are smaller than those that the Atlantic Royal Flycatchers selected in CBSP, or are even absent (pers. obs.). It is difficult to infer if these birds are specialized to the point of ceasing reproduction in these areas, or if they could change their reproductive niche in response to habitat disturbance. However, as larger streams tend to provide more protection against nest predators than the smaller ones (Small and Hunter 1988; Ocampo and Londoño 2015), the lack of adequate streams also could contribute to lower nest survival in many forest remnants. It is also important to note that with such a low territorial density, at least about $16 \mathrm{~km}$ of forest streams would be needed to maintain, for instance, 25 reproductive territories. Although this number has been roughly considered enough to maintain only the short-term viability of populations (Jamieson and Allendorf 2012), many Atlantic Forest fragments are too small to preserve this extension of streams (Ribeiro et al. 2009).

Due to the apparent low population densities of Royal Flycatchers in general (Robinson and Terborgh 1997; Johnson et al. 2011), addressing the frequencies of nesting pairs along streams could be a viable way to assess the conservation status of the global reproductive population of Atlantic Royal Flycatchers. Then, detailed mapping of streams with the above described characteristics along the large Atlantic Forest continuum from southeastern Brazil should be in the agenda of conservation managers.

\section{Conclusions}

In conclusion, nesting habitat specificity, low annual fecundity, and low breeding territory density may be among the factors contributing to the rarity of the Atlantic Royal Flycatcher in large forest continuums and to its total absence in fragmented environments. The needs for large extensions of forest streams with the characteristics specified above, in well-preserved forest tracts, are plausible explanations for the persistence of the Atlantic Royal Flycatcher only in the large forest continuums from the coast of São Paulo and Paraná states. It reinforces the importance of these areas for the conservation of specialized bird species. 


\section{Supplementary Information}

The online version contains supplementary material available at https://doi. org/10.1186/s40657-020-00237-2.

Additional file 1: Stream variables and nest site selection data.

\section{Acknowledgments}

The authors are grateful to Danilo da Costa Silva for the preparation of the images, to Marco and Patrícia for the reception at Trilha dos Tucanos Lodge, and to Bianca Matinata, Carlos Biagolini, Carolina Oliveira, Cristiane Apolinário, Felipe Arantes, Lais Ribeiro-Silva, Lucas Andrei, Marcelo Feliti, Marcelo Morena, Matheus Santos, Michele Viana, Renato Martins, and Wagner Lacerda for field support. Instituto Florestal do Estado de São Paulo (IF), and ICMBio provided authorizations for field work at Carlos Botelho State Park and Trilha dos Tucanos Lodge (permits ICMBio 54231-3, COTEC 71/2014 D184/2013 AP, 455/2016 D89/2016, and 555/2017 D89/2016 PH). We are also especially grateful for two anonymous referees for important suggestions on previous versions of this manuscript.

\section{Authors' contributions}

DFP, PVQZ and MRF designed the project. DFP, PVQZ, and MRF performed the field works. DFP and MRF analyzed the data. DFP and MRF wrote the manuscript. All authors read and approved the final manuscript.

\section{Funding}

This work was funded by the Brazilian agencies Fundação de Amparo à Pesquisa do Estado de São Paulo - FAPESP (Project SISBIOTA network-Top predators 2010/52315-7). Daniel F. Perrella and Paulo V.Q. Zima received fellowships from Conselho Nacional de Desenvolvimento Científico e Tecnológico (CNPq), and Mercival R. Francisco receives a productivity research fellowship from CNPq (Proc\# 308702/2019-0).

\section{Availability of data and materials}

The datasets supporting the conclusions are available in an excel Additional file 1.

\section{Ethics approval and consent to participate}

The authors assert that all procedures were in compliance with the ethical standards of the Comissão de Ética no Uso de Animais da Universidade Federal de São Carlos- CEUA (authorization number 5091100816).

\section{Consent for publication}

Not applicable.

\section{Competing interests}

All the authors declare that they have no competing interests.

\section{Author details}

${ }^{1}$ Programa de Pós-Graduação em Ecologia e Recursos Naturais, Universidade Federal de São Carlos, Washington Luiz km 235, São Carlos 13565-905, Brazil. ${ }^{2}$ Departamento de Ciências Ambientais, Universidade Federal de São Carlos, Rod. João Leme dos Santos km 110, Sorocaba 18052-780, Brazil.

Received: 30 July 2020 Accepted: 14 December 2020

Published online: 05 January 2021

\section{References}

Aguilar TM, Maldonado-Coelho M, Marini MA. Nesting biology of the Gray-hooded Flycatcher (Mionectes rufiventris). Ornitol Neotrop. 2000;11:223-30.

Alves RRN, Lima JRF, Araújo HFP. The live bird trade in Brazil and its conservation implications: an overview. Bird Conserv Int. 2012;23:53-65.

Anciães M, Aguilar TM, Leite LO, Andrade RD, Marini MA. Nesting biology of the Yellow-olive Flatbill (Tyrannidae, Elaninae) in Atlantic Forest fragments in Brazil. Wilson J Ornithol. 2012;124:547-57.
Anjos L, Boçon R. Bird communities in natural forest patches in southern Brazil. Wilson Bull. 1999;111:397-414.

Antunes AZ, Eston MR. Avifauna do Parque Estadual Alberto Löfgren-São Paulo: diagnóstico e propostas para a conservação. Rev Inst Flor. 2008;20:195-211.

Antunes AZ, Silva BG, Matsukuma CK, Eston MR, Santos AMR. Aves do Parque Estadual Carlos Botelho - SP. Biota Neotrop. 2013;13:01-17.

Armacost JW Jr. The nest, eggs and nestlings of the Castelnau's Antshrike (Thamnophilus cryptoleucus), with notes on its ecology and conservation. Wilson Bull. 2004;116:262-6.

Ayres ACM. O Ciclo da Caapora: A RMSP e o Parque da Cantareira. São Paulo: Annablume; 2008.

Bates D, Mächler M, Bolker B, Walker S. Fitting linear mixed-effects models using Ime4. J Stat Softw. 2015;67:1-48.

Beisiegel BM, Mantovani W. Habitat use, home range and foraging preferences of the coati Nasua nasua in a pluvial tropical Atlantic forest area. J Zool. 2006;269:77-87.

Bencke GA, Maurício GN, Develey PF, Goerck JM. Áreas importantes para a conservação das aves no Brasil: parte 1-estados do domínio da Mata Atlântica. São Paulo: SAVE Brasil; 2006.

Beissinger SR. Ecological mechanisms of extinction. PNAS. 2000;97:11688-9.

BirdLife International. Onychorhynchus swainsoni. The IUCN Red List of Threatened Species. 2019. https://doi.org/10.2305/IUCN.UK.2018-2.RLTS.T2269 9659A131326693.en(2018) (Accessed 1 Jan 2019).

Birskis-Barros I, Alencar LRV, Prado PI, Böhm M, Martins M. Ecological and conservation correlates of rarity in New World Pitvipers. Diversity. 2019;11:147.

Brocardo CR, Rodarte R, Bueno RS, Culot L, Galetti M. Mamíferos não voadores do Parque Estadual Carlos Botelho Continuum florestal do Paranapiacaba. Biota Neotrop. 2012;12:01-11.

Chalfoun AD, Schmidt KA. Adaptive breeding-habitat selection: is it for the birds? Auk. 2012a;129:589-99.

Cheng L, Zhou L, Wu L, Feng G. Nest site selection and its implications for conservation of the endangered Oriental Stork Ciconia boyciana in Yellow River Delta. China Bird Conserv Int. 2019:30:323-34.

Cockle KL, Brodati AA, Lammertink M, Bonaparte EB, Ferreyra CFS, Di Sallo FG. Predators of bird nests in the Atlantic forest of Argentina and Paraguay. Wilson J Ornithol. 2016;128:120-31.

Cornell KL, Donovan TM. Effects of spatial habitat heterogeneity on habitat selection and annual fecundity for a migratory forest songbird. Landsc Ecol. 2010;25:109-22.

Chalfoun AD, Schmidt KA. Adaptive breeding-habitat selection: is it for the birds. Auk. 2012b;129:589-99.

Collias NE, Collias EC. Nest building and bird behaviour. Princeton: Princeton University Press; 1984.

Cuthbert R, Sommer E, Ryan P, Cooper J, Hilton G. Demography and conservation of the Tristan Albatross Diomedea [exulans] dabbenena. Biol Conserv. 2004;117:471-81

Dário FR, De Vincenzo MCV, Almeida AF. Avifauna em fragmentos da Mata Atlântica. Cienc Rural. 2002;32:989-96.

Davanço PV, Oliveira LS, Souza LMS, Francisco MR. Breeding life-history traits of the Pale-breasted Thrush (Turdus leucomelas) in southeastern Brazil. Ornitol Neotrop. 2013:24:401-11.

Delhey K, Carrizo M, Verniere LC, Mahler B, Peters A. Seazonal variation in reproductive output of a Neotropical temperate suboscine the Firewood-gatherer (Annumbius annumbi). Auk. 2010;127:222-31.

Del Hoyo J, Collar N, Kirwan GM. Atlantic Royal Flycatcher (Onychorhynchus swainsoni). In: del Hoyo J, Elliott A, Sargatal J, editors. Handbook of the Birds of the World. Barcelona: Lynx Edicions; 2019. https://www.hbw. com/node/1343672. Accessed 1 Dec 2019.

Descourtilz JT. História natural das aves do Brasil (ornitologia brasileira): notáveis por sua plumagem, canto e hábitos. Belo Horizonte: Itatiaia; 1983.

Dinsmore SJ, White GC, Knopf FL. Advanced techniques for modeling avian nest survival. Ecology. 2002;83:3476-88.

Donatelli RJ, Ferreira CD, Dalbetoand AC, Posso SR. Análise comparativa da assembleia de aves em dois remanescentes florestais no interior do Estado de São Paulo. Brasil Rev Bras Zool. 2007;24:362-75.

Ferraz LPM, Varjabedian R. Evolução histórica da implantação e síntese das informações disponíveis sobre o Parque Estadual Carlos Botelho. São Paulo: Instituto Florestal; 1999. 
Fitzpatrick JW. Foraging behavior of Neotropical Tyrant Flycatchers. Condor. 1980;82:43-57.

Fondell TF, Ball IJ. Density and success of bird nests relative to grazing on western Montana grasslands. Biol Conserv. 2004;117:203-13.

Gilpin ME, Soulé ME. Minimum viable populations: processes of species extinction. In: Soulé ME, editor. Conservation Biology, the science of scarcity and diversity. Suderland: Sinauer Associates; 1986. p. 125-39.

Gjerdrum C, Elphick CS, Rubega M. Nest site selection and nesting success in salt marsh breeding Sparrows: the importance of nest habitat, timing, and study site differences. Condor. 2005;107:849-62.

Goerck JM. Patterns of rarity in the birds of the Atlantic Forest of Brazil. Conserv Biol. 1997:11:112-8.

Greeney HF, Dingle C, Dobbs RC, Martin PR. Natural history of Streak-necked Flycatcher Mionectes striaticollis in north-east Ecuador. Cotinga. 2006;25:59-64.

Groves CR, Jensen DB, Valutis LL, Redford KH, Shaffer ML, Scott JM, et al. Planning for biodiversity conservation: putting conservation science into practice. Bioscience. 2002;52:499-512.

Harnik PG, Simpson C, Payne JL. Long-term differences in extinction risk among the seven forms of rarity. Proc R Soc B. 2012;279:4969-76.

Harrell FEJr. Hmisc: Harrell Miscellaneous. R package version 4.2-0. 2019. https ://CRAN.R-project.org/package=Hmisc. Accessed 1 Jan 2018.

Hasui E, Metzger JP, Pimentel RG, Silveira LF, Bovo AAB, Martensen AC, et al. Atlantic birds: a data set of bird species from the Brazilian Atlantic Forest. Ecology. 2018;99:497.

Horton RE. Erosional development of streams and their drainage basins: hydrophysical approach to quantitative morphology. Geol Soc Am Bull. 1945;56:275-370.

Ibáñez-Álamo JD, Magrath RD, Oteyza JC, Chalfoun AD, HaffTM, Schmidt KA et al. Nest predation research: recent findings and future perspectives. J Ornithol. 2015:156:S247-62.

Jamieson IG, Allendorf FW. How does the 50/500 rule apply to MVPs? Trends Ecol Evol. 2012;27:578-84.

Jetz W, Sekercioglu CH, Böhning-Gaese K. The worldwide variation in avian clutch size across species and space. PLoS Biol. 2008:6:2650-7.

Johnson El, Stouffer PC, Vargas CF. Diversity, biomass, and trophic structure of a Central Amazonian Rainforest bird community. Rev Bras Ornitol. 2011:9:1-16.

Kirwan GM. Notes on the breeding ecology and seasonality of some Brazilian birds. Rev Bras Ornitol. 2009;17:121-36.

Laake JL. RMark: An R interface for analysis of capture-recapture data with MARK. R package version 2.2.6. 2013. https://cran.rproject.org/web/ packages/RMark/index.html. Accessed 1 Jan 2018.

Lemmon PE. A new instrument for measuring forest overstorey density. J For Res. 1957:55:667-9.

Lima RAF, Dittrich VAO, Souza VC, Salino A, Breier TB, Aguiar OT. Flora vascular do Parque Estadual Carlos Botelho, São Paulo. Brasil Biota Neotrop. 2011;11:173-214.

Linhares KV, Soares FA, Machado CS. Nest support plants of the Araripe Manakin Antilophia bokermanni, a critically endangered endemic bird from Ceará. Brazil Cotinga. 2010;32:121-5.

Londoño GA. Parque Nacional del Manu, Cusco, Perú Anidación de Aves en un Gradiente Altitudinal. Chicago: Science and Education; 2014.

Lopes LE, Marini MA. Biologia reprodutiva de Suiriri affinis e S. islerorum (Aves: Tyrannidae) no Cerrado do Brasil Central. Pap Avulsos Zool. 2005:45:127-41.

Lu X. Hot genome leaves natural histories cold. Adv Sci Lett. 2015;349:1064

Machado RB, Silveira LF, Silva MISG, Ubaid FK, Medolago CA, Francisco MR, et al. Reintroduction of songbirds from captivity: the case of the Greatbilled Seed-finch (Sporophila maximiliani) in Brazil. Biodivers Conserv. 2020;29:1613-36.

Maia-Gouvêa ER, Gouvêa E, Piratelli A. Comunidade de aves de sub-bosque em uma área de entorno do Parque Nacional do Itatiaia, Rio de Janeiro. Brasil Rev Bras Zool. 2005:22:859-66.

Mallet-Rodrigues F, Guentert M, Kirwan G. Records of Atlantic Royal Flycatcher Onychorhynchus coronatus swainsoni from Santa Catarina, southern Brazil. Cotinga. 2006;26:06-8.

Mallet-Rodrigues F, Parrini R, Pacheco JF. Birds of the Serra dos Órgãos, State of Rio de Janeiro, Southeastern Brazil: a review. Rev Bras Ornitol. 2007;15:05-35.
Marques-Santos F, Braga TV, Wischhoff U, Roper JJ. Breeding biology of passerines in the subtropical Brazilian Atlantic Forest. Ornitol Neotrop. 2015:26:363-74.

Martin TE. Nest predation and nest sites. Bioscience. 1993;43:523-32.

Martin TE, Geupel GR. Nest-monitoring plots: methods for locating nests and monitoring success. J Field Ornithol. 1993;64:507-19.

Mattoso AQ, Pisciotta K, Barros MIA, Maia JLC, Lorejan SF. Parque Estadual Carlos Botelho, Plano de Manejo. São Miguel Arcanjo: Instituto Ekos Brasil; 2008

Mayfield H. Nesting success calculated from exposure. Wilson Bull. 1961;73:255-61.

Mezquida ET. Nest site selection and nesting success of five species of passerines in a South American open Prosopis woodland. J Ornithol. 2004;145:16-22.

Myers N, Mittermeier RA, Mittermeier CG, Fonseca GAB, Kent J. Biodiversity hotspots for conservation priorities. Nature. 2000;403:853-8.

Newmark WD, Stanley TR. Habitat fragmentation reduces nest survival in an Afrotropical bird community in a biodiversity hotspot. PNAS. 2011;108:11488-93.

Noske RA, Mulyani YA, Lloyd P. Nesting beside old nests, but not over water, increases current nest survival in a tropical mangrove-dwelling warbler. J Ornithol. 2013;154:517-23.

Ocampo D, Londoño GA. Tropical montane birds have increased nesting success on small river islands. Auk. 2015:132:01-10.

Oliveira LS, Sousa LMS, Davanço PV, Francisco MR. Breeding behavior of the Lined Seedeater (Sporophila lineola) in southeastern Brazil. Ornitol Neotrop. 2010;21:251-61.

Oliveira-Filho AT, Fontes MAL. Patterns of floristic differentiation among Atlantic forests in southeastern Brazil and the influence of climate. Biotropica. 2000;32:793-810.

Oniki Y. Is nesting success of birds low in the tropics? Biotropica. 1979;11:60-9.

Owens IPF, Bennett PM. Ecological basis of extinction risk in birds: Habitat loss versus human persecution and introduced predators. PNAS. 2000;97:12144-8.

Pacífico EC, Barbosa EA, Filadelfo T, Oliveira KG, Silveira LF, Tella JL. Breeding to non-breeding population ratio and breeding performance of the globally endangered Lear's Macaw Anodorhynchus leari: conservation and monitoring implications. Bird Conserv Int. 2014;24:466-76.

Parker TA III, Stotz DF, Fitzpatrick JW. Ecological and distributional databases. In: Stotz DF, Fitzpatrick JW, Parker TA, Moskovits DK, editors. Neotropical birds: ecology and conservation. Chicago: University of Chicago Press; 1996. p. 113-436.

Peck ME. Protective adaptation in the nesting habits of some Central American birds. Proc lowa Acad Sci. 1908;15:177-82.

Pense MR, Carvalho APC. Biodiversidade de aves do Parque Estadual do Jaraguá (SP). Conscientiae Saúde. 2005;4:55-61.

Perrella DF, Biagolini-Júnior CH, Ribeiro-Silva L, Zima PVQ, Galetti Junior PM, Francisco MR. Nest, eggs, and nestlings of the Atlantic Forest endemic Star-throated Antwren (Rhopias gularis). Wilson J Ornithol. 2015;127:322-6.

Perrella DF, Biagolini Junior CH, Ribeiro-Silva L, Zima PVQ, Francisco MR. Reproduction of the Atlantic Forest endemic Star-throated Antwren, Rhopias gularis (Aves: Thamnophilidae). Braz J Biol. 2017;77:356-60.

Perrella DF, Ferrari DS, Katayama MV, Paiva RV, Guida FJV. A Avifauna do Parque Estadual das Fontes do Ipiranga, um remanescente de Mata Atlântica imerso na área urbana de São Paulo. SP Ornithologia. 2018;10:04-16.

Perrella DF, Zima PVQ, Ribeiro-Silva L, Biagolini CH Jr, Carmignotto AP, Galetti PM Jr, et al. Bats as predators at nests of tropical forest birds. J Avian Biol. 2020;51:e02277.

Pinto O. Sobre a coleção Carlos Estevão de peles, ninhos e ovos das aves de Belém (Pará). Pap Avulsos Zool. 1953;11:111-222.

Piratelli A, Andrade VA, Filho ML. Aves de fragmentos florestais em área de cultivo de cana-de-açúcar no sudeste do Brasil. Iheringia. 2005;95:217-22.

Primack RB. Essentials of conservation Biology. Sunderland: Sinauer Associates; 2006.

R Core Team. R: A language and environment for statistical computing. R Foundation for Statistical Computing. 2017. https://www.R-project.org/. Accessed 30 Oct 2018.

Ribeiro MC, Metzger JP, Martensen AC, Ponzoni FJ, Hirota MM. The Brazilian Atlantic Forest: How much is left, and how is the remaining forest distributed? Implications for conservation. Biol Conserv. 2009:142:1141-53. 
Ribeiro-Silva L, Perrella DF, Biagolini-Jr CH, Zima PVQ, Piratelli AJ, Schlindwein MN, et al. Testing camera traps as a potential tool for detecting nest predation of birds in a tropical rainforest environment. Zoologia. 2018;35:e14678.

Ribon R, Simon JE, Mattos GT. Bird extinctions in Atlantic Forest fragments of the Viçosa region. Southeastern Brazil Conserv Biol. 2003;17:1827-39.

Robinson SK. Coloniality in the Yellow-rumped Cacique as a defense against nest predators. Auk. 1985;102:506-19.

Robinson SK, Terborgh J. Bird community dynamics along primary successional gradients of an Amazonian whitewater river. Ornithol Monogr. 1997:48:641-72.

Robinson WD, Sherry TW. Mechanisms of avian population decline and species loss in tropical forest fragments. J Ornithol. 2012;153:S141-52.

Rodrigues VB, Jesus FM, Campo RI. Local habitat disturbance increases bird nest predation in the Brazilian Atlantic rainforest. Anim Biodiv Conserv. 2018;41:117-20.

Roldán-Clarà B, LaPergola JB, Chapa-Vargas L, Calmé S. Nest survival in the Neotropical Black Catbird (Melanoptila glabrirostris). J Ornithol. 2013;154:491-9.

Roper JJ. Try and try again: nest predation favors persistence in a Neotropical bird. Ornitol Neotrop. 2005;16:253-62.

Schunck F, Melo MA, Sanches LA, Godoy FI, Martins GG, Mix P. Avifauna do Parque Ecológico do Guarapiranga e sua importância para a conservação das aves da Região Metropolitana de São Paulo. Ornithologia. 2016;9:35-57.

Sick H. Ornitologia brasileira. Rio de Janeiro: Nova Fronteira; 1997.

Skutch AF. Incubation and nesting periods of Central American birds. Auk. 1945;62:08-37.

Skutch AF. Life histories of Central American birds II: Families Vireonidae, Sylviidae, Turdidae, Troglodytidae, Paridae, Corvidae, Hirundinidae and Tyrannidae. Berkeley: Cooper Ornithological Society; 1960.

Small MF, Hunter ML. Forest fragmentation and avian nest predation in forested landscapes. Oecologia. 1988;76:62-4.

Tashian RE. Some birds from the palenque region of Northeastern Chiapas. México Auk. 1952;69:60-6.

Tellkamp MP, Martin TH. Noteworthy bird records from southern Yucatán state. México Cotinga. 2015;37:18-21.
Terborgh J. Preservation of natural diversity: the problem of extinction prone species. Bioscience. 1974;24:715-22.

Tonetti VR, Rego MA, de Luca AC, Develey PF, Schunck F, Silveira LF. Historical knowledge, richness and relative representativeness of the avifauna of the largest native urban rainforest in the world. Zoologia. 2017;34:e13728.

Ubaid FK, Silveira LF, Medolago CB, Costa TVV, Francisco MR, Barbosa KVC, et al. Taxonomy, natural history, and conservation of the Great-billed SeedFinch Sporophila maximiliani (Cabanis, 1851) (Thraupidae, Sporophilinae). Zootaxa. 2018:4442:551-71.

Von Ihering $\mathrm{H}$. Novas contribuições para a ornitologia do Brasil. Rev Mus Paul. 1914;9:411-88.

Wetmore A. The birds of the Republic of Panamá, part 3, Passeriformes: Dendrocolaptidae (Woodcreepers) to Oxyruncidae (Sharpbills). Smithson Misc Collect. 1972;150:1-631.

White GC, Burnham KP. Program MARK: Survival estimation from populations of marked animals. Bird Study. 1999;46:S120-39.

Whittingham MJ. Observations at a nest of the Pacific Royal Flycatcher Onychorhynchus coronatus occidentalis. Bull Br Ornithol Club. 1994;114:131-2.

Willis EO. The composition of avian communities in remanescent woodlots in Southern Brazil. Pap Avulsos Zool. 1979;33:01-25.

Winkler DW. Nests, eggs, and young: the breeding biology of birds. In: Podulka S, Rohrbaugh, RW, Bonney R, Handbook of bird biology. Ithaca: Cornell Lab of Ornithology; 2004. p. 8.1-8.152.

Xiao H, Hu Y, Lang Z, Fang B, Guo W, Zhang Q, et al. How much do we know about the breeding biology of bird species in the world? J Avian Biol. 2016:47:1-6.

Zima PVQ, Perrella DF, Biagolini-Jr CH, Ribeiro-Silva L, Francisco MR. Breeding behavior of the Atlantic forest endemic Blue Manakin (Chiroxiphia caudata). Wilson J Ornithol. 2017;129:53-61.

Zoellick BW, Ulmschneider HM, Cade BS, Stanley AW. Isolation of Snake River islands and mammalian predation of waterfowl nests. J Wildlife Manage. 2004;68:650-62.

Zhu X, Srivastava DS, Smith JNM, Martin K. Habitat selection and reproductive success of Lewis's Woodpecker (Melanerpes lewis) at its northern limit. PLOS ONE. 2012;7:e44346.
Ready to submit your research? Choose BMC and benefit from:

- fast, convenient online submission

- thorough peer review by experienced researchers in your field

- rapid publication on acceptance

- support for research data, including large and complex data types

- gold Open Access which fosters wider collaboration and increased citations

- maximum visibility for your research: over 100M website views per year

At BMC, research is always in progress.

Learn more biomedcentral.com/submissions 